\section{Validity and Reliability of the Turkish version of the Severity Measure for Specific Phobia - Child Form According to DSM-5}

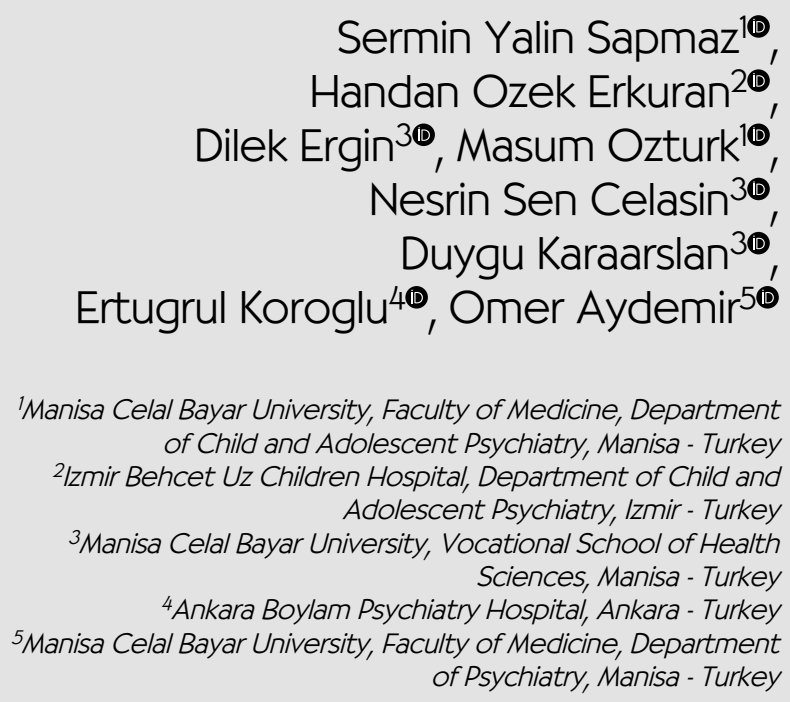

Sermin Yalin Sapmaz ${ }^{1 \oplus}$, Handan Ozek Erkuran ${ }^{20}$ Dilek Ergin ${ }^{30}$, Masum Ozturk ${ }^{10}$, Nesrin Sen Celasin ${ }^{30}$ Duygu Karaarslan ${ }^{30}$ Ertugrul Koroglu ${ }^{4 \oplus}$, Omer Aydemir ${ }^{5}$

'Manisa Celal Bayar University, Faculty of Medicine, Department of Child and Adolescent Psychiatry, Manisa - Turkey 2lzmir Behcet Uz Children Hospital, Department of Child and Adolescent Psychiatry, Izmir - Turkey ${ }^{3}$ Manisa Celal Bayar University, Vocational School of Health Sciences, Manisa - Turkey ${ }^{4}$ Ankara Boylam Psychiatry Hospital, Ankara - Turkey ${ }_{5}^{5}$ Manisa Celal Bayar University, Faculty of Medicine, Department of Psychiatry, Manisa - Turkey

\section{ABSTRACT}

Validity and reliability of the Turkish version of the Severity Measure for Specific Phobia - Child Form according to DSM-5

Objective: This study aimed to assess the validity and reliability of the Turkish version of the Severity Measure for Specific Phobia - Child Form according to DSM-5.

Method: The study group consisted of 50 patients treated in a child psychiatry unit and diagnosed with any specific phobia and 100 healthy volunteers. For the assessment, the Screen for Childhood Anxiety and Related Emotional Disorders (SCARED) was used along with the Severity Measure for Specific Phobia Child Form according to DSM-5.

Results: For reliability, Cronbach's alpha internal consistency coefficient was calculated to be 0.961 . Testretest correlation coefficient was calculated $r=0.750$. As for construct validity, one factor that could explain $74.1 \%$ of the variance was obtained, which is consistent with the original structure of the scale. As for concurrent validity, the correlation coefficient with the SCARED in children is $r=0.480$.

Conclusion: It was concluded that the Turkish version of the DSM-5 Severity Measure for Specific Phobia - Child Form can be utilized as a valid and reliable tool both in clinical practice and for research purposes. Keywords: DSM-5, reliability, Severity Measure for Specific Phobia, validity

\section{Öz}

DSM-5 Özgül Fobi Şiddet Ölçeği - Çocuk Formunun Türkçe güvenilirliği ve geçerliliği Amaç: Bu çallşmada DSM-5 Özgül Fobi Şiddet Öıçeği - Çocuk Formunun Türkçe sürümünün güvenilirliği ve geçerliliğinin çalışılması amaçlanmıştır.

Yöntem: Araştırma grupları çocuk psikiyatri kliniğinde tedavi gören ve özgül fobi tanısı alan 50 hasta ile 100 sağ|lkı gönüllüden oluşmaktadır. Değerlendirmede DSM-5 Özgül Fobi Şiddet Ölçeği - Çocuk Formunun yanı sıra Çocukluk Çağı Anksiyete Tarama Ölçeği (ÇATÖ) kullanıımıştır.

Bulgular: Güvenilirlik analizlerinde Cronbach alfa iç tutarlılık katsayısı 0.961'dir. Test-yeniden test bağıntı katsayısı r=0.750 olarak hesaplanmıştır. Yapı geçerliliğinde varyansın \%74.1ini açıklayan bir faktör elde edilmiştir ve ölçeğin orijinal yapısı ile uyumludur. DSM-5 Özgül Fobi Şiddet Ölçeği - Çocuk Formunun, ÇATÖ ile yapılan birlikte geçerlilik çözümlemesinde bağıntı katsayısı $r=0.480$ 'dir.

Sonuç: DSM-5 Özgül Fobi Şiddet Ölçeği - çocuk Formu Türkçe sürümünün hem klinik uygulamada hem araştırmalarda güvenilir ve geçerli biçimde kullanılabileceği gösterilmiştir.

Anahtar kelimeler: DSM-5, güvenilirlik, Özgül Fobi Şiddet Ölçeği, geçerlilik
How to cite this article: Yalin-Sapmaz S, OzekErkuran $\mathrm{H}$, Ergin D, Ozturk M, Sen-Celasin N, Karaarslan D, Koroglu E, Aydemir O. Validity and reliability of the Turkish version of the Severity Measure for Specific Phobia - Child Form according to DSM-5. Dusunen Adam The Journal of Psychiatry and Neurological Sciences 2018;31:340-346. https://doi.org/10.5350/DAJPN2018310402 


\section{INTRODUCTION}

S pecific phobia, one of the most commonly seen $S$ anxiety disorders, manifests itself in a distinct and continuous feeling of anxiety related to a determined object or a situation. Phobic stimuli are either effectively avoided or endured with intense fear or anxiety. The experience of fear and anxiety is continuous. At the same time, fear and anxiety are disturbing the individual's daily functionality. In the DSM-IV and DSM-5, 5 subtypes of specific phobia have been defined, namely, related to animals, natural environment, blood-needle-injury, situational, and other $(1,2)$.

Studies in children and adolescents found a prevalence for specific phobias of between 2.4 and $7.9 \%$ (3). Research in general population samples found comorbidity with other specific phobias of around $50.0 \%$ and with other anxiety disorders a co-occurrence of $25.0 \%$. In a clinical sample, a higher association with other anxiety disorders is to be expected (4). Work on adults determined that a diagnosis of specific phobia meant that functionality in their work and education environment was disrupted, working days lost, and the quality of life was reduced both physically and mentally (5). It has also been established that specific phobias in children can lead to academic, social, and individual problems affecting day-to-day functionality, and furthermore, they can correlate with other anxiety disorders, mood disorders, and substance-use disorders that may develop later on $(6,7)$.

The course of the illness is usually chronic, while the number of phobic persons seeking treatment is quite low. One study found that within 1 year, 15.8\% came for treatment (8). The fact that signs of phobia are only triggered by a specific situation or object, while the person can conduct their life avoiding the specific situation, may reduce the frequency of reporting to psychiatry. As specific phobias co-occur with a number of other psychiatric conditions, especially other anxiety disorders, its symptoms may stay in the shadow of a comorbid disease and thus escape the clinicians' attention.
The $5^{\text {th }}$ edition of the DSM was released in May, 2013 (2). The most important change was an addition of a dimensional approach to the traditional categorical classification. Significant criticism had been raised against the categorical system with only two values (either the patient carries a given disorder or not). A dimensional assessment of a psychopathology allows clinicians and researchers to evaluate the intensity of a disorder and the appearance of sub-threshold signs. With renewed assessments, changes of symptoms over time can be monitored $(9,10)$. With the publication of the DSM5 diagnostic manual, the need arose to develop new instruments measuring intensity as well as monitoring the course of a condition, and for a number of psychiatric diseases, new assessment instruments were proposed in accordance with the DSM-5 criteria (11).

The Severity Measure for Specific Phobia - Child Age 11-17 form according to DSM-5 is a scale consisting of 10 items. The instrument is designed to be completed by a child that has received a diagnosis of specific phobia (or shown significant specific phobia symptoms clinically) before subsequent follow-up consultations with the clinician. In particular, the first 5 item concern feelings of anxiety and fear regarding encountered objects or situations and the second 5 items are related with behavior to avoid the respective object or situation (11).

This work constitutes a validity and reliability study for the use of the Severity Measure for Specific Phobia - Child Age 11-17 scale according to DSM-5 in Turkey.

\section{METHOD}

In order to adapt the Severity Measure for Specific Phobia - Child Age 11-17 scale to Turkish, permission was obtained from HYB Publisher and Boylam Institute of Psychiatry, who are holding the translation and publication rights for the DSM-5 handbook and the scales it contains. The scale was translated by two child psychiatrists working in the field of child and adolescent mental health and illness and by an adult 
psychiatry specialist working in the area of mental health and illness. This translation was checked and a text was agreed that was adequate in meaning, use of language, cultural and conceptual appropriateness, and correct spelling. The text was retranslated into English by an adult psychiatrist. This translation was then compared with the original scale for consistency of the concepts it contained. After receiving the required confirmation, the text of the scale was composed. In order to check for clarity of the text and possible application problems, the Turkish scale was administered to 10 children reporting to the policlinic with any diagnosis of an anxiety disorder; no problems were noted.

\section{Sample Group}

This study was performed after obtaining ethics approval from the Clinical Research Assessment Committee of the Medical Faculty of Manisa Celal Bayar University.

A literature survey found various numbers and views regarding the sample size required for multivariate analyses of the validity of scales such as factorial analyses. One of the opinions gave a ratio according to the number of items. According to Tavsancil (12), the sample size should be at least 5 times or even 10 times greater than the number of variants or items. For this purpose, we determined a number of 100 subjects in the healthy student group. Criteria for the inclusion in the general population sample were an age between 11 and 17 years, the absence of any mental disorder or physical illness diagnosis, and a sufficient cognitive capacity to carry out the research instructions. With the population sample, no structured clinical interview was held. All patients and their parents were administered a sociodemographic data form asking about the presence of mental and physical diseases. Information provided by child and parents was accepted as true.

In order to establish if the scale could discriminate the population sample from a clinical sample, we set up a clinical sample of 50 adolescents between the ages of 11 and 17 years consulting the Child
Psychiatry Outpatient Unit of Manisa Celal Bayar University Medical Faculty who had received a diagnosis of specific phobia. While determining the number for the patient group, we established the size of the healthy group sample using the abovementioned method suggested by Tavsancil (12), planning to include a number that was at least 5 times that of the number of items. The diagnoses of the patient group were made on the basis of the classification in the DSM-5. Inclusion criteria were an age between 11 and 17 years, a diagnosis of specific phobia according to DSM-5 criteria, and a sufficient cognitive capacity to follow the research instructions. Exclusion criterion was the presence of any physical or neurological disease requiring continuous treatment.

\section{Measures}

\section{Severity Measure for Specific Phobia - Child} Age 11-17 scale: An instrument containing 10 items to determine the severity of specific phobia in children and adolescents. In each item, a rating of the severity of specific phobia symptoms experienced over the past 7 days is requested. Each item on the scale is rated on a 5 -point-scale $(0=$ Never; $1=$ Occasionally; $2=$ Half of the time; $3=$ Most of the time, and $4=$ All of the time). The total score ranges between 0 and 40 points. Higher scores show more severe symptoms of specific phobia. During the clinical interview, the clinician is asked to review each item score and record a raw score in the section for "clinician use". Raw scores for the 10 items are added up to generate a raw total score. In addition, the clinician needs to calculate the average total score, which converts the general score into a fivepoint-scale, reaching an assessment of the severity of the specific phobia ranked as none (0), mild (1), moderate (2), severe (3), or extreme (4). The average total score is calculated dividing the raw score by the number of items in the scale (i.e., 10). A study made in a general population sample in Holland with children between the ages of 8 and 13 years found the scale to be valid and reliable (10). 
Screen for Child Anxiety and Related Emotional Disorders (SCARED): This was developed by Birmaher et al. (13) with the aim to screen for childhood anxiety disorders. SCARED contains a parent form and a child form. The validity and reliability for the Turkish version was confirmed by Cakmakci (14). SCARED contains a parent form and a child form. The validity and reliability for the Turkish version was confirmed in 2004 by Cakmakci (14). The scale consists of 41 items, and a score of 25 and above is accepted as an indication for the presence of an anxiety disorder. The instrument comprises subscales for panic disorder/somatic symptoms, generalized anxiety, separation anxiety, social anxiety disorder, and school avoidance (14).

\section{Research Plan and Schedule}

Data for the study were collected between May 2015 and May 2016. Cases seen during this period that matched the inclusion criteria and accepted to participate were assessed according to suitability to be included and according to exclusion criteria; then, they were informed about the study topic and a written "Informed voluntary consent form" was received. To assess the validity of the scale, the Severity Measure for Specific Phobia and the SCARED were administered. In order to measure test-retest reliability at the same time, 41 healthy children were administered the Severity Measure for Specific Phobia again after 2 weeks.

\section{Statistical Analysis}

Reliability was analyzed calculating Cronbach's alpha internal consistency coefficient for the data from all study groups. Test-retest reliability was established after administering the Severity Measure for Specific Phobia again to 41 healthy volunteers, two weeks after the first use, and calculating the correlation coefficient between the two administrations.

To assess the construct validity of the scale, explanatory factor analysis was carried out for data from all study groups. To control sampling adequacy,
Kaiser-Meyer-Olkin test and Bartlett test were used. Explanatory factor analysis was done with the principal component method using varimax rotation; factors with an eigenvalue of 1 or above were included in the evaluation. The structure resulting from the explanatory factor analysis was compared with the original dimension structure. In addition, correlation between the Severity Measure for Specific Phobia - Child Form and the SCARED was considered.

The capacity to discriminate between population and clinical samples was shown using the Receiver Operating Characteristic ( $\mathrm{ROC}$ ) curve. An area under the ROC curve of 0.9 and above showed a good discrimination for the scale, a value between 0.8 and 0.9 an acceptable discrimination.

\section{Findings}

The research was carried out with 50 patients attending the Child Psychiatry Policlinic of Manisa Celal Bayar University with a diagnosis of specific phobia and 100 healthy volunteers. Sociodemographic and clinical characteristics of the research groups are shown in Table 1.

In 41 of the 50 cases in the patient group (72\%), a comorbidity was diagnosed, including generalized anxiety disorder (14 cases), attention-deficit/ hyperactivity disorder (14 cases), social anxiety disorder (5 cases), major depressive disorder (4 cases), separation anxiety disorder (3 cases), agoraphobia (2 cases), and panic disorder (1 case). Regarding the sources of their phobias, 20 cases suffered from fear of blood, needles, and injury, 11 cases had a phobia related to animals, 8 cases experienced fear for situational reasons, and 8 cases had other reasons (choking or vomiting), while 7 cases had phobias related to the natural environment.

\section{Reliability Analysis}

Reliability analysis for the Severity Measure for Specific Phobia resulted in a Cronbach's alpha 
Table 1: Sociodemographic characteristics of the study groups

\begin{tabular}{|c|c|c|c|c|}
\hline & \multicolumn{2}{|c|}{$\begin{array}{c}\text { Specific phobia } \\
n=50\end{array}$} & \multicolumn{2}{|c|}{$\begin{array}{l}\text { Healthy group } \\
\quad n=100\end{array}$} \\
\hline & Mean & SD & Mean & SD \\
\hline \multirow[t]{2}{*}{$\overline{\text { Age* }}$} & 14.2 & 2.2 & 15.7 & 1.1 \\
\hline & $\mathbf{n}$ & $\%$ & $\mathbf{n}$ & $\%$ \\
\hline \multicolumn{5}{|l|}{ Gender } \\
\hline Female & 29 & 58 & 42 & 40 \\
\hline \multirow[t]{2}{*}{ Male } & 21 & 42 & 58 & 58 \\
\hline & Mean & SD & Mean & SD \\
\hline \multicolumn{5}{|l|}{ Scales used* } \\
\hline Severity Measure for Specific Phobia & 24.0 & 7.2 & 9.2 & 11.6 \\
\hline Screen for Childhood Anxiety and Related Emotional Disorders & 34.5 & 15.0 & 21.8 & 13.9 \\
\hline
\end{tabular}

SD: Standard deviation, ${ }^{*} p<0.05$

Table 2: Cronbach's alpha coefficients, item-total correlation coefficients by item, and factor loading for the Severity Measure for Specific Phobia form

\begin{tabular}{|c|c|c|c|}
\hline & $\begin{array}{l}\text { Cronbach's } \\
\text { alpha } \\
\text { coefficients }\end{array}$ & $\begin{array}{l}\text { Item-total } \\
\text { correlation } \\
\text { coefficients }\end{array}$ & $\begin{array}{l}\text { Factor } \\
\text { loading }\end{array}$ \\
\hline Felt moments of sudden terror, fear, or fright in these situations & 0.955 & 0.879 & 0.906 \\
\hline Felt anxious, worried, or nervous about these situations & 0.954 & 0.890 & 0.915 \\
\hline Had thoughts of being injured, overcome with fear, or other bad things happening in these situations. & 0.957 & 0.828 & 0.864 \\
\hline Felt a racing heart, sweaty, trouble breathing, faint, or shaky in these situations. & 0.955 & 0.868 & 0.897 \\
\hline Felt tense muscles, felt on edge or restless, or had trouble relaxing in these situations. & 0.957 & 0.824 & 0.859 \\
\hline Avoided, or did not approach or enter, these situations. & 0.956 & 0.828 & 0.879 \\
\hline Moved away from left these situations early or participated very little. & 0.956 & 0.854 & 0.885 \\
\hline Spent a lot of time preparing for, or procrastinating about (i.e., putting off), these situations. & 0.957 & 0.820 & 0.854 \\
\hline Distracted myself to avoid thinking about these situations. & 0.958 & 0.791 & 0.831 \\
\hline Needed help to cope with these situations (e.g., alcohol or medications, superstitious objects, other people) & 0.963 & 0.647 & 0.700 \\
\hline
\end{tabular}

consistency coefficient of 0.961 . Cronbach's alpha for each item is shown in Table 2. Item-total score correlation coefficients were found in the range of 0.647 to 0.890 (Table 2). Test-retest analysis, using data from 41 volunteers, found the data to be adequate for analysis, resulting in a correlation coefficient for the two administrations at a distance of two weeks of $r=0.750(p<0.0001)$.

\section{Validity Analysis}

Explanatory factor analysis was used to establish the construct validity of the Severity Measure for Specific Phobia - Child form according to DSM-5. First, Kaiser-Meyer-Olkin test was carried out to control for the adequacy of the sample group, finding a coefficient of 0.941 . The Bartlett test calculated a chi-square of $1584.542(p<0.0001)$. Thus, the sampling was shown to be adequate for factor analysis.

In the factor analysis, one factor with an eigenvalue of above 1 was found; the eigenvalue is 7.413 and explains $74.1 \%$ of the variance. Factor loadings are shown in Table 2.

A concurrent validity analysis for the Severity Measure for Specific Phobia - Child form according to DSM-5 and the SCARED found a correlation coefficient of $r=0.480(p<0.0001)$.

The ROC analysis of the Severity Measure for Specific Phobia - Child form, including the specific phobia group and the healthy volunteer group, found an area under the ROC curve of 0.843 . 


\section{DISCUSSION}

This study has adapted the Severity Measure for Specific Phobia - Child form in its Turkish version, examined its reliability and validity, and shown the usability of the Turkish version.

The study that originally developed the instrument in the adult group found a Cronbach's alpha coefficient of 0.83 in a general population sample and 0.96 in a clinical sample (9). A reliability study in the child group found a Cronbach's alpha coefficient of 0.84 (10). In psychometric assessments, the closer Cronbach's alpha is to 1 , the higher the reliability of the test is considered (15). In our study, Cronbach's alpha for internal consistency was 0.96 , which is a high value, showing that the structure of the scale adequately represents the total. Item-total correlation coefficients were also found to be high, confirming the reliability of the scale's structure.

Test-retest analysis in the original study in adults resulted in a correlation coefficient of $r=0.51$ between the iterations (9). In our study, the correlation coefficient was $\mathrm{r}=0.75$, a high and statistically significant value. In the light of these results, we conclude that the scale can be used reliably.

In the concurrent validity analysis, we looked at the correlation with the SCARED. In the first study carried out with children, a correlation coefficient of 0.42 had been found (10). In our study, like in other studies with children, the correlation is at an intermediate level $(\mathrm{r}=0.48)$. While still statistically significant, the correlation coefficient is low. The SCARED has no special subscale for specific phobia; nor are there items investigating avoidance symptoms, which may account for the low correlation coefficient.

Explanatory factor analysis was applied to the Severity Measure for Specific Phobia - Child form according to DSM-5. We obtained a factor with an eigenvalue above 1 . The eigenvalue of the first factor was 7.413 , explaining $74.1 \%$ of the original variance, which is consistent with the original structure (16). Conceptualizing specific phobia symptoms within a single-factor structure showed the instrument's high specificity for the symptom cluster of specific phobia. Thus the clinician obtains clear data about the severity of specific phobia uncontaminated by confounding factors. The use of this instrument facilitates the clinician's following the intensity of specific phobia.

Construct validity as well as concurrent validity of the scale emphasize that it is a valid instrument to use.

The first limitation of this study is its use in the control group of a clinical interview structured with the aim to investigate a diagnosis. In addition, when assessing the differences obtained in the comparative analysis of the items of the scale, we need to keep in mind that there was an age difference between patient group and controls. In accordance with the aims of our study, all statistical analyses could be carried out with a sample group the size of ours. One strength of our study is that the sample was representative for patients, thus demonstrating the clinical usefulness of the scale.

\begin{tabular}{|c|c|c|}
\hline \multicolumn{2}{|c|}{ Contribution Categories } & \multirow{2}{*}{$\begin{array}{l}\text { Author Initials } \\
\text { S.Y.S., O.A., E.K. }\end{array}$} \\
\hline \multirow{3}{*}{ Category 1} & Concept/Design & \\
\hline & Data acquisition & M.O., D.E., N.S.C., D.K. \\
\hline & Data analysis/Interpretation & S.Y.S., O.A., H.O.E. \\
\hline \multirow[t]{2}{*}{ Category 2} & Drafting manuscript & $\begin{array}{l}\text { S.Y.S., O.A., M.O., D.E., } \\
\text { N.S.C., D.K. }\end{array}$ \\
\hline & Critical revision of manuscript & S.Y.S., O.A., H.O.E., E.K. \\
\hline Category 3 & Final approval and accountability & $\begin{array}{l}\text { S.Y.S., O.A., M.O., D.E., } \\
\text { N.S.C., D.K., H.O.E., E.K. }\end{array}$ \\
\hline \multirow{3}{*}{ Other } & Technical or material support & N/A \\
\hline & Supervision & N/A \\
\hline & Securing funding (if applicable) & N/A \\
\hline
\end{tabular}

Informed Consent: Written consent was obtained from the participants.

Peer-review: Externally peer-reviewed.

Conflict of Interest: Authors declared no conflict of interest.

Financial Disclosure: Authors declared no financial support. 


\section{REFERENCES}

1. American Psychiatric Association. Diagnostic and Statistical Manual of Mental Disorders. Fourth ed., Washington, D.C: American Psychiatric Association, 2000.

2. American Psychiatric Association. Diagnostic and Statistical Manual of Mental Disorders. Fifth ed., Washington, D.C: American Psychiatric Association, 2013.

3. Kim SJ, Kim BN, Cho SC, Kim JW, Shin MS, Yoo HJ, Kim HW The prevalence of specific phobia and associated comorbid features in children and adolescents. J Anxiety Disord 2010; 24:629-634. [CrossRef]

4. Ollendick TH, Raishevich N, Davis TE, Sirbu C, Ost LG Specific phobia in youth: phenomenology and psychological characteristics. Behav Ther 2010; 41:133-141. [CrossRef]

5. Mogotsi M, Kaminer D, Stein DJ. Quality of life in the anxiety disorders. Harv Rev Psychiatry 2000; 8:273-282. [CrossRef]

6. Kendall PC, Safford S, Flannery-Schroeder E, Webb A. Child anxiety treatment: outcomes in adolescence and impact on substance use and depression at 4-year follow-up. J Consult Clin Psychol 2004; 72:276-287. [CrossRef]

7. Essau CA, Conradt J, Petermann F. Frequency, comorbidity, and psychosocial impairment of anxiety disorders in German adolescents. J Anxiety Disord 2000; 14:263-279. [CrossRef]

8. Essau CA, Conradt J, Petermann F. Frequency, comorbidity and psychosocial impairment of specific phobia in adolescents. J Clin Child Psychol 2000; 29:221-231. [CrossRef]
9. Lebeau RT, Glenn DE, Hanover LN, Beesdo-Baum K, Wittchen HU, Craske MG. A dimensional approach to measuring anxiety for DSM-5. Int J Methods Psychiatr Res 2012; 21:258-272.

\section{[CrossRef]}

10. Moller EL, Majdandzic M, Craske MG, Bogels SM. Dimensional assessment of anxiety disorders in parents and children for DSM5. Int J Methods Psychiatr Res 2014; 23:331-344. [CrossRef]

11. American Psychiatric Association. Online Assessment Measures. https://www.psychiatry.org/FileLibrary/Psychiatrists/Practice/ DSM/APA_DSM5_Severity-Measure-For-Specific-Phobia-ChildAge-11-to-17.pdf Accessed May 1, 2018.

12. Tavsancil E. Measuring Attitudes and Data Analysis with SPSS. Ankara: Nobel Publishing and Distribution, 2006. (Turkish)

13. Birmaher B, Brent DA, Chiapetta L, Bridge J, Monga S, Baugher M. Psychometric properties of the screen for Child Anxiety Related Emotional Disorders (SCARED): a replication study. J Am Acad Child Adolesc Psychiatry 1999; 38:1230-1236. [CrossRef]

14. Cakmakci FK. Validity and reliability study for an anxiety disorder screening instrument in children. Specialization Thesis, Kocaeli University Medical Faculty, Kocaeli, 2004. (Turkish)

15. Koroglu E, Aydemir O, Turkcapar H. Study Design, Method, and Control in Psychiatry. Ankara: HYB Publisher, 2012. (Turkish)

16. Beesdo-Baum K, Klotsche J, Knappe S, Craske MG, Lebeau RT, Hoyer J, Strobel A, Pieper L, Wittchen HU. Psychometric properties of the dimensional anxiety scales for DSM-V in an unselected sample of German treatment seeking patients. Depress Anxiety 2012; 29:1014-1024. [CrossRef] 